\title{
Treg Cells Protect Dopaminergic Neurons against MPP+ Neurotoxicity via CD47- SIRPA Interaction
}

\author{
Yan Huanga,b Zhan Liu ${ }^{\mathrm{b}}$ Bei-Bei Cao ${ }^{\mathrm{b}} \quad$ Yi-Hua Qiu ${ }^{\mathrm{b}} \quad$ Yu-Ping Peng ${ }^{\mathrm{b}}$ \\ aSchool of Biological \& Basic Medical Sciences, Soochow University, Suzhou, bepartment of \\ Physiology, School of Medicine, and Co-innovation Center of Neuroregeneration, Nantong University, \\ Nantong, China
}

\section{Key Words}

Regulatory T cells • Parkinson's disease • Dopaminergic neurons $\cdot C D 47 \cdot$ Signal regulatory protein $\alpha$

\begin{abstract}
Background/Aims: Regulatory T (Treg) cells have been associated with neuroprotection by inhibiting microglial activation in animal models of Parkinson's disease (PD), a progressive neurodegenerative disease characterized by dopaminergic neuronal loss in the nigrostriatal system. Herein, we show that Treg cells directly protect dopaminergic neurons against 1-methyl4-phenylpyridinium $\left(\mathrm{MPP}^{+}\right)$neurotoxicity via an interaction between the two transmembrane proteins CD47 and signal regulatory protein $\alpha$ (SIRPA). Methods: Primary ventral mesencephalic (VM) cells or VM neurons were pretreated with Treg cells before $\mathrm{MPP}^{+}$treatment. Transwell co-culture of Treg cells and VM neurons was used to assess the effects of the Treg cytokines transforming growth factor (TGF)- $\beta 1$ and interleukin (IL)-10 on dopaminergic neurons. Live cell imaging system detected a dynamic contact of Treg cells with VM neurons that were stained with CD47 and SIRPA, respectively. Dopaminergic neuronal loss, which was assessed by the number of tyrosine hydroxylase (TH)-immunoreactive cells, was examined after silencing CD47 in Treg cells or silencing SIRPA in VM neurons. Results: Treg cells prevented MPP+-induced dopaminergic neuronal loss and glial inflammatory responses. TGF- $\beta 1$ and IL-10 secreted from Treg cells did not significantly prevent MPP+-induced dopaminergic neuronal loss in transwell co-culture of Treg cells and VM neurons. CD47 and SIRPA were expressed by Treg cells and VM neurons, respectively. CD47-labeled Treg cells dynamically contacted with SIRPA-labeled VM neurons. Silencing CD47 gene in Treg cells impaired the ability of Treg cells to protect dopaminergic neurons against MPP ${ }^{+}$toxicity. Similarly, SIRPA knockdown in VM neurons reduced the ability of Treg cell neuroprotection. Rac1/Akt signaling pathway in VM neurons was activated by CD47-SIRPA interaction between Treg cells and the neurons. Inhibiting Rac1/ Akt signaling in VM neurons compromised Treg cell neuroprotection. Conclusion: Treg cells protect dopaminergic neurons against $\mathrm{MPP}^{+}$neurotoxicity by a cell-to-cell contact mechanism underlying CD47-SIRPA interaction and Rac1/Akt activation.
\end{abstract}




\section{Cellular Physiology Cell Physiol Biochem 2017;41:1240-1254 \\ \begin{tabular}{ll|l} 
and BiOChemistry & $\begin{array}{l}\text { DOI: 10.1159/000464388 } \\
\text { Published onlIne: March 07, } 2017\end{array}$ & $\begin{array}{l}\text { C } 2017 \text { The Author(s). Published by S. Karger AG, Basel } \\
\text { www.karger.com/cpb }\end{array}$
\end{tabular} \\ Huang et al.: Treg Cells Protect Neurons against MPP+ Toxicity}

\section{Introduction}

Accumulating evidence indicates that $\mathrm{T}$ lymphocytes are involved in neuroimmune activities in the brain of Parkinson's disease (PD), a neurodegenerative disease characterized by progressive degeneration of dopaminergic neurons in the nigrostriatal system [1-3]. $\mathrm{T}$ lymphocytes infiltrate into the brain and locate around degenerating dopaminergic neurons with activated microglia in both patients with PD and models of PD [4-6]. Since $\mathrm{T}$ lymphocytes have several subpopulations that play different roles in immune responses, they may exert different effects in PD processes. For example, T helper (Th)17 cells, the pro-inflammatory $\mathrm{CD} 4{ }^{+} \mathrm{CD} 25^{-} \mathrm{T}$ lymphocytes, exacerbate PD pathology and symptoms by promoting microglial excessive activation or by directly damaging dopaminergic neurons in our and other reports [6, 7]. Regulatory T (Treg) cells, the Foxp3-expressing CD4 ${ }^{+} \mathrm{CD} 25^{+}$ T lymphocytes, are originally termed "suppressor cells" [8] and are pivotal in suppressing autoimmunity and maintaining immune homeostasis [9, 10-12]. A growing body of evidence shows that Treg cells are not only important for maintaining immune balance at the periphery but also contribute to self-tolerance and immune privilege in the central nervous system [13]. Treg cells isolated from PD patients show decreased ability to suppress function of effector T cells from healthy allogeneic donors, suggesting a dysfunction of Treg cells during PD progression [14]. Adoptive transfer of CD3-activated Treg cells to 1-methyl4-phenyl-1,2,3,6-tetrahydropyridine (MPTP)-intoxicated mice provides greater than $90 \%$ protection of the nigrostriatal system, and the neuroprotection of Treg cells is achieved through suppression of microglial oxidative stress and inflammation [15]. Combinations of adoptively transferred nitrated alpha-synuclein and Treg cells to MPTP mice attenuate microglial inflammatory responses and lead to robust nigrostriatal protection [6]. These reports support a notion that Treg cells implement neuroprotection through inhibition of microglial inflammatory responses. Therefore we questioned whether Treg cells directly act on dopaminergic neurons to exert neuroprotection in PD processes.

Animal cells communicate with each other in two principal ways: 1) they secrete chemicals that signal to cells at some distance; and 2) they express a signaling molecule at the cell surface that binds to a cognate receptor on adjacent cells [16]. Treg cells suppress inflammatory and immune responses by secreting anti-inflammatory cytokines such as transforming growth factor (TGF)- $\beta 1$ and interleukin (IL)-10 $[17,18]$. This regulatory way of Treg cells belongs to the first communication system. In the brain, the anti-inflammatory cytokines impair inflammatory milieu and glial activation but enhance the stabilization of the blood-brain barrier, and therefore they have neuroprotective properties $[19,20]$. Nevertheless, the anti-inflammatory cytokine TGF- $\beta 1$ does not directly act on dopaminergic neurons to protect them against the toxicity of 1-methyl-4-phenylpyridinium ( $\mathrm{MPP}^{+}$), a toxic cation that is concentrated in dopaminergic neurons via presynaptic dopamine transporters to kill the neurons, in our recent study [19]. We have demonstrated that microglia are required for mediation of TGF- $\beta 1$ neuroprotection against $\mathrm{MPP}^{+}$toxicity [19]. Thus, the second communication way between Treg cells and dopaminergic neurons was investigated in the present study to better understand the rationality of Treg cell neuroprotection.

One recently identified cell-cell communication system is composed of the transmembrane proteins CD47 and signal regulatory protein $\alpha$ (SIRPA) [16]. CD47 is widely expressed in most cell types and functions as a ligand for SIRPA [21, 22]. SIRPA is especially abundant in neurons and in macrophages, dendritic cells and neutrophils [23-25]. Interaction of CD47 with SIRPA occurs between host-derived cells, and is mostly related to cell signaling in the immune and nervous systems [16]. For example, upon binding CD47, SIRPA on macrophages initiates a signaling cascade that results in inhibition of phagocytosis by the cells [21]. Activation of SIRPA through interaction with CD47 also regulates development of dendritic cells and neuronal network formation $[16,26]$. However, whether the interaction of CD47 on Treg cells with SIRPA on dopaminergic neurons mediates a neuroprotection of Treg cells needs clarification. 


\section{Cellular Physiology Cell Physiol Biochem 2017;41:1240-1254

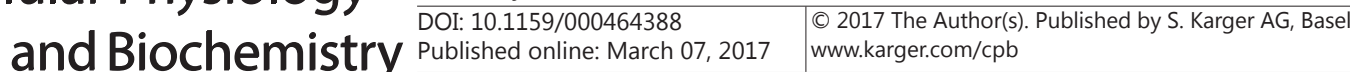

Ligation of SIRPA by CD47 promotes tyrosine phosphorylation of the former protein in macrophages [27, 28] and endothelial cells [25]. Upon phosphorylation, SIRPA activates Src homology-2 (SH2) domain containing protein phosphatases SHP-1 and/or SHP-2 [29]. SHP-2 regulates function of small GTP-binding proteins, Ras and Rho [16]. Rac1, a Rho family GTPase, participates in regulation of cytoskeletal reorganization, cellular growth, and apoptosis via activation of downstream signaling such as Akt, a serine/threonine kinase [30, 31]. Thus, the signaling pathway Rac1/Akt in neurons was also examined in this study to explain an involvement of the intracellular transducer in CD47/SIRPA-mediated Treg cell neuroprotection.

Accordingly, in the presentstudy, we firstly demonstrated that Treg cells prevented MPP+induced dopaminergic neuronal loss and glial mediator disorders in ventral mesencephalic (VM) cell cultures; secondly we identified that the cytokines TGF- $\beta 1$ and IL-10 secreted from Treg cells that were co-cultured with VM neurons via a transwell system did not significantly protect dopaminergic neurons against $\mathrm{MPP}^{+}$toxicity; thirdly we established that CD47SIRPA interaction mediated Treg cell contact protection to dopaminergic neurons; and lastly we showed that neuronal Rac1/Akt signaling transduced the information of CD47-SIRPA interaction-mediated Treg cell neuroprotection.

\section{Materials and Methods}

\section{Primary VM cell culture}

The preparation of VM cells was based on a previously described method [32]. Anesthetized pregnant C57BL/6J mice on embryonic day $13 \pm 0.5$ (E13 \pm 0.5 ) were decapitated and embryonic pups were removed aseptically. The VM tissues of embryos were collected, washed with Hank's Balanced Salt Solution (HBSS) at $4^{\circ} \mathrm{C}$, and incubated in $2 \mathrm{ml}$ of pre-warmed $2.5 \mathrm{mg} / \mathrm{ml}$ trypsin solution (Gibco, USA) for $12 \mathrm{~min}$ at $37^{\circ} \mathrm{C}$. Cells were subsequently centrifuged and resuspended in complete DMEM medium (Invitrogen, USA) containing $10 \%$ fetal bovine serum (Invitrogen, USA). Cell suspensions were plated onto poly-D-lysine-coated 24well plates or 6-well plates at a density of $5 \times 10^{5}$ cells $/ \mathrm{cm}^{2}$, which were incubated at $37^{\circ} \mathrm{C}$ in a humidified $5 \% \mathrm{CO}_{2} / 95 \%$ air atmosphere incubator (Thermo $8000 \mathrm{WJ}$, USA). The seven-day-old cultures were used in subsequent experiments.

\section{Primary VM neuron-enriched culture}

To inhibit glial proliferation, cytosine arabinoside $(10 \mu \mathrm{M})$ was added to primary VM cell cultures that were described above at $24 \mathrm{~h}$ after the cells were plated. The cultures were considered as VM neuronenriched cultures. The six-day-old neuron-enriched cultures, which contain $>90 \%$ NeuN-immunoreactive neurons [33], were employed in subsequent experiments.

\section{Isolation and culture of Treg cells}

The protocol followed the instructions of $\mathrm{CD} 4^{+} \mathrm{CD} 25^{+}$Treg cell isolation kit (Miltenyi Biotec, Germany). Briefly, C57BL/6J mice were sacrificed after deep anesthesia, and single-cell suspensions were prepared from the spleens. $\mathrm{CD} 4^{+} \mathrm{T}$ cell populations from the spleens were enriched by negative selection and $\mathrm{CD} 4{ }^{+} \mathrm{CD} 25^{+}$ cells from $\mathrm{CD}^{+} \mathrm{T}$ cells were enriched by positive selection. The $\mathrm{CD} 4^{+} \mathrm{CD} 25^{+}$cells, which were used as Treg cells, were analyzed by flow cytometry for the purity of $\mathrm{CD} 4^{+} \mathrm{CD} 25^{+} \mathrm{Foxp} 3^{+}$cells. The $\mathrm{CD} 4^{+} \mathrm{CD} 25^{+} \mathrm{Foxp} 3^{+}$ cells accounted for 93-95\%, which is consistent with the report [34]. To activate Treg cells, the cells were incubated with $2 \mu \mathrm{g} / \mathrm{ml}$ anti-CD3 and $2 \mu \mathrm{g} / \mathrm{ml}$ anti-CD28 (both from BD Biosciences, USA) for 4 days at a density of $1 \times 10^{6}$ cells $/ \mathrm{ml}$ in complete RPMI 1640 (Invitrogen, USA) supplemented with 10\% FBS, 2 mM L-glutamine, $25 \mathrm{mM}$ HEPES, $1 \mathrm{mM}$ sodium pyruvate, 13 nonessential amino acids, $55 \mathrm{nM} 2-\mathrm{ME}, 100 \mathrm{U} / \mathrm{ml}$ penicillin, and $100 \mathrm{mg} / \mathrm{ml}$ streptomycin (Gibco, USA).

\section{Co-culture of Treg cells with VM cells or VM neurons}

Activated Treg cells were rinsed and resuspended in complete DMEM medium, which was added to seven-day-old VM cell cultures or seven-day-old VM neuron cultures at a ratio of 1:1. After Treg cells were co-cultured with VM cells or VM neurons for $1 \mathrm{~h}, \mathrm{MPP}^{+}$(Sigma, USA) was applied to the co-cultures at a 


\section{Cellular Physiology Cell Physiol Biochem 2017;41:1240-1254

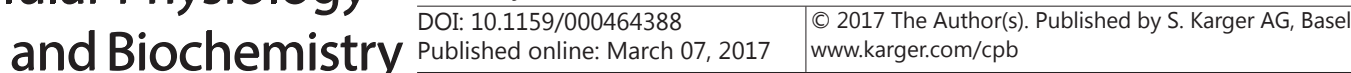

Huang et al.: Treg Cells Protect Neurons against MPP ${ }^{+}$Toxicity

concentration of $5 \mu \mathrm{M}$. After $24 \mathrm{~h}$ of incubation, the co-cultures were washed with PBS to removed Treg cells. The remaining VM cells or VM neurons were subjected to subsequent analysis.

\section{Transwell co-culture of Treg cells and VM neurons}

Activated Treg cells were rinsed and resuspended in complete DMEM medium at a density of $5 \times 10^{5}$ cells $/ \mathrm{ml}$, which was transferred into a transwell cell culture chamber, bottom of which was comprised of a membrane with 0.4- $\mu \mathrm{m}$ pore size (Millipore, USA). The transwell chamber containing Treg cells was placed into the 24-well culture plate containing seven-day-old VM neurons. The ratio of Treg cells to VM neurons was 1:1. After co-culture for $1 \mathrm{~h}, \mathrm{MPP}^{+}$(Sigma, USA) was applied to VM neurons in the lower 24-well plate at a concentration of $5 \mu \mathrm{M}$. After $24 \mathrm{~h}$ of incubation, the transwell chamber was removed, and the supernatants and the neurons in the lower 24-well plate were collected to detect cytokine levels and neuronal number, respectively.

RNA isolation and real-time PCR assays

The co-cultures of Treg cells and VM cells were washed with 0.01 M PBS at least three times to remove the suspended Treg cells. Total RNA was extracted from cultured VM cells using TRIzol reagent (Invitrogen, USA) and converted to cDNA using cDNA reverse transcription kit (Invitrogen, USA). Real-time quantitative PCR was performed on cDNA in the Rotor-Gene 3000 Real-time Cycler (Corbett Research, Australia) with SYBR green I as the detection system. The primer sequences were as follows: 5 '-CAT CTT CTC AAA ATT CGA GTG ACA A-3' and 5'-TGG GAG TAG ACA AGG TAC AAC CC-3' for TNF- $\alpha$; 5'-CCA GGG CAT GTT AAG GAG CT-3' and 5'-CCA TCA GAG GCA AGG AGG AA-3' for IL-1 $\beta$; 5'-GGG ACG CTT GGT GGT TGA T-3' and 5'-ATG AGA ATG CTG CCG AAA A-3' for GDNF; 5'-AAA AGC AGC CCG CTC TAT C-3' and 5'-TTC CGA GTT GCC TCC GTT A-3' for IGF-1; 5'-CAA CAA TCT CCA CTT TGC CAC TG-3' and 5'-AAA TGG TGA AGG TCG GTG TGA AC-3' for GAPDH. The GAPDH was used as normalization control for genes.

\section{Western blotting analysis}

The co-cultures of Treg cells with VM cells or VM neurons were washed with 0.01 M PBS to remove the suspended Treg cells. Proteins in the remaining VM cells or VM neurons were extracted with lysis buffer ( $62.5 \mathrm{mM}$ Tris-HCl at pH 6.8, 2\% SDS, 4\% $\beta$-mercaptoethanol, 10\% glycerol, $50 \mathrm{mM}$ DTT, and $1 \mathrm{mM}$ phenylmethanesulfonyl). Protein samples ( $30 \mu \mathrm{g}$ per lane) were fractionated by SDS-PAGE on $12 \%$ gels, and were then transferred onto polyvinylidene difluoride membranes (Millipore, USA). The membranes were probed using antibodies against TNF- $\alpha$ (1:400, Abcam, UK), IL-1 $\beta$ (1:200, Santa Cruz Biotechnology, USA), GDNF (1:500, Abcam, UK), IGF-1 (1:200, Santa Cruz Biotechnology, USA), phosphor-Akt (1:1000, Cell Signaling, USA), Bcl-xL (1:1000, Cell Signaling, USA), or cleaved caspase-3 (1:1000, Cell Signaling, USA). Monoclonal anti- $\beta$-actin antibody was included as an internal standard to monitor loading errors. Appropriate IRDye 800-conjugated secondary antibodies (1:5000, Rockland Immunochemicals, USA) were used to visualize blots using Odyssey laser scanning system (LI-COR Inc., USA). The band intensities of each protein in control and with treatments were measured using NIH Image J software and expressed as relative values normalized to $\beta$-actin.

\section{Rac1 activity pull-down assay}

Assays were performed using a Rac1 activation assay kit, according to the manufacturer's recommendations (Millipore, USA). Cells were lysed in $\mathrm{Mg}^{2+}$ lysis buffer containing protease inhibitors and phosphatase inhibitors, followed by centrifugation to remove cell debris. Equal amounts $(0.5 \mathrm{mg})$ of total protein were incubated with $10 \mu \mathrm{l}$ of agarose-conjugated p21-binding domain of PAK1, which binds activated Rac1, for $1 \mathrm{~h}$ at $4^{\circ} \mathrm{C}$. The agarose beads were washed three times in lysis buffer, resuspended in 20 $\mu \mathrm{l} 4 \times$ SDS loading buffer, and boiled for $10 \mathrm{~min}$. Active (GTP-bound) Rac1 and total Rac1 were analyzed by Western blotting.

\section{Immunocytochemistry}

The co-cultures of Treg cells and VM neurons were washed with 0.01 M PBS to remove the suspended Treg cells. The remaining VM cells or VM neurons were fixed with 4\% PFA, washed three times with 10 $\mathrm{mM}$ PBS, and incubated for $40 \mathrm{~min}$ at room temperature in $10 \mathrm{mM}$ PBS containing $10 \%$ normal goat serum (Gibco, USA) and $0.3 \%$ Triton X-100. The VM cells or VM neurons were incubated with primary antibodies 


\section{Cellular Physiology Cell Physiol Biochem 2017;41:1240-1254 \\ \begin{tabular}{l|l|l} 
and Biochemistry $\begin{array}{l}\text { DOI: 10.1159/000464388 } \\
\text { Published } 2017\end{array}$ & $\begin{array}{l}\text { @ } 2017 \text { The Author(s). Published by S. Karger AG, Basel } \\
\text { www.karger.com/cpb }\end{array}$
\end{tabular}}

Huang et al.: Treg Cells Protect Neurons against MPP+ Toxicity

including mouse anti-TH at 1:400 (Millipore, USA) and rabbit anti-NeuN at 1:200 (Millipore, USA) for $48 \mathrm{~h}$ at $4^{\circ} \mathrm{C}$. Goat secondary antibodies conjugated to FITC or Alexa Fluor 594 (1:200, Jackson, USA) were used for fluorescence detection. Pictures were collected by a fluorescence microscopy (Leica, Germany) at 200× magnification. The sum of $\mathrm{TH}^{+} \mathrm{NeuN}^{+}$neuronal number in 25 visual fields of each coverslip was reported as statistic value for a sample, and the average $\mathrm{TH}^{-} \mathrm{NeuN}^{+}$neuronal number in 5 visual fields of each coverslip was reported as statistic value for a sample.

For co-expression of TH and SIRPA/CD47, or co-expression of Foxp3 and SIRPA/CD47, the co-cultures of Treg cells and VM neurons were fixed with 4\% PFA, washed three times with $10 \mathrm{mM}$ PBS, and incubated for $40 \mathrm{~min}$ at room temperature in $10 \mathrm{mM}$ PBS containing 10\% normal goat serum (Gibco, USA) and $0.3 \%$ Triton X-100. Both the cells were co-incubated with primary antibodies against TH (1:400, Millipore, USA) and SIRPA (1:200, Abcam, UK)/CD47 (1:1000, Abcam, UK), or Foxp3 (1:200, Santa Cruz Biotechnology, USA) and SIRPA/CD 47 for $48 \mathrm{~h}$ at $4^{\circ} \mathrm{C}$. The corresponding secondary antibodies goat anti-rabbit Alexa Fluor 594 and goat anti-mouse FITC (both 1:200, Jackson, USA) were used for fluorescence detection. Pictures were collected by a fluorescence microscopy (Leica, Germany) at 200× magnification.

Quantization of cytokine levels by enzyme-linked immunosorbent assay (ELISA)

TGF- $\beta 1$ and IL-10 levels in supernatants of VM neuron cultures in lower chamber of transwell coculture were quantified by ELISA kits according to the manufacturer's instruction (eBioscience, USA). Briefly, $50 \mu \mathrm{l}$ of supernatants were added to the ELISA plate, which was incubated for $2 \mathrm{~h}$ at room temperature. After washing, $100 \mu \mathrm{l}$ of respective HRP-conjugated IgG polyclonal antibody was added to each well of the ELISA plate, which was incubated for $2 \mathrm{~h}$. After $30 \mathrm{~min}$ of incubation with $100 \mu \mathrm{l}$ of substrate solution at room temperature protected from light, $100 \mu \mathrm{l}$ of stop solution was added, and optical density was determined using a multi-mode microplate reader (Bio Tek, USA) at $450 \mathrm{~nm}$. A standard curve was plotted from mean absorbance of each standard sample and the cytokine levels were calculated according to the standard curve.

Time-lapse video microscopy

Treg cells and VM neurons were prepared as described above. Treg cells were incubated with anti-CD47 antibody (1:100, Abcam, UK) and VM neurons were cultured with anti-SIRPA antibody (1:100, Abcam, UK) both in PBS containing $1 \%$ bovine serum albumin at $37^{\circ} \mathrm{C}$ for $1 \mathrm{~h}$, followed by incubation with appropriate Alexa Fluor-conjugated secondary antibodies (1:200, Molecular Probes, USA). After staining, both SIRPAlabeled VM neurons and CD47-labeled Treg cells were transferred to a co-culture chamber filled with 1.5 $\mathrm{ml}$ of complete DMEM medium. The co-culture chamber was placed under a microscope (Leica AF6000, Germany) connected to a digital camera and an incubator. Images were taken every $20 \mathrm{~s}$ at a magnification of $200 \times$ for up to $6 \mathrm{~h}$ using automated software.

Construction and transfection of CD47-miRNA expression vector

CD47-miRNA expression vector (pcDNA/miR-CD47; Invitrogen, USA) was constructed and transfected into Treg cells using nucleofection technology (Amaxa biosystems, Germany). The transfection protocol followed the instructions of mouse $\mathrm{T}$ cell nucleofector kit (Amaxa Biosystems, Germany). Briefly, after incubated with anti-CD3 and anti-CD28 for $48 \mathrm{~h}$, Treg cells were resuspended in $100 \mu \mathrm{l}$ of T cell nucleofector solution. Plasmid of $4 \mu \mathrm{g}$ was added to $100 \mu \mathrm{l}$ of $5 \times 10^{6}$ Treg cell suspension. The mixtures were subsequently transferred to an electroporation cuvette, which was placed in the nucleofection device (Amaxa Biosystems, Germany). After nucleofection of these cells were accomplished using X-001 program, the samples were immediately transferred to 24-well plates containing $2 \mathrm{ml}$ pre-warmed media. Interference efficiency was assessed by Western blotting analysis at $48 \mathrm{~h}$ after the transfection. The sequences of the single-stranded oligonucleotides targeting CD47 were as follows:

5‘-TGC TGT CAA CTT CCA CTT CAC AAA CAG TTT TGG CCA CTG ACT GAC TGT TTG TGG TGG AAG TTG A-3' for top chain and 5'-CCT GTC AAC TTC CAC CAC AAA CAG TCA GTC AGT GGC CAA AAC TGT TTG TGA AGT GGA AGT TGA C-3' for bottom chain. The sequences of scrambled oligonucleotides (Scr-miRNA) used as control were as follows: 5'-tgc tgA AAT GTA CTG CGC GTG GAG ACG TTT TGG CCA CTG ACT GAC GTCT CCA CGC AGT ACA TTT-3' for top chain and 5'-cct gAA ATG TAC TGC GTG GAG ACG TCA GTC AGT GGC CAA AAC GTC TCC ACG CGC AGT ACA TTT c-3’ for bottom chain. 
Construction and transfection of lentiviral vector expressing SIRPA-shRNA

A shRNA sequence targeting mouse SIRPA (Gene Bank Accession NM_001177646) was designed into 5'-GTT CAA AGA TGG GCA AGA A-3'. A scrambled shRNA (Scr-shRNA) sequence (5'-TTC TCC GAA CGT GTC ACG T-3') was used as control. The lentiviral vectors expressing SIRPA-shRNA and Scr-shRNA were generated by Genechem Co. Ltd. (China). The recombinant lentiviruses were prepared to a titer of $8 \times 10^{8}$ transducing units $/ \mathrm{ml}$ and transfected into VM neurons at a multiplicity of infection of 10. Transfection efficiency was assessed by SIRPA expression level in the cells at $72 \mathrm{~h}$ after the transfection.

\section{Statistical analysis}

Data were expressed as means \pm standard deviations $(\mathrm{M} \pm \mathrm{SD}$ ). Statistical analyses were performed with the Statistics Package for Social Science (SPSS, 12.0). The data were subjected to one-way ANOVA, followed by Student-Newman-Keul's test to compare the data of all groups relative to each other. Differences were considered statistically significant at $p<0.05$.

\section{Results}

Treg cells prevent MPP+-induced dopaminergic neuronal loss and glial mediator expression disorders in VM cell cultures

$\mathrm{MPP}^{+}$significantly decreased $\mathrm{TH}^{+} \mathrm{NeuN}^{+}$cell number in VM cell cultures (Fig. 1A). Treg cell pretreatment prevented the $\mathrm{MPP}^{+}$-induced dopaminergic neuronal loss (Fig. 1A). Treg cell exposure alone (no $\mathrm{MPP}^{+}$treatment) did not significantly alter $\mathrm{TH}^{+} \mathrm{NeuN}^{+}$cell number
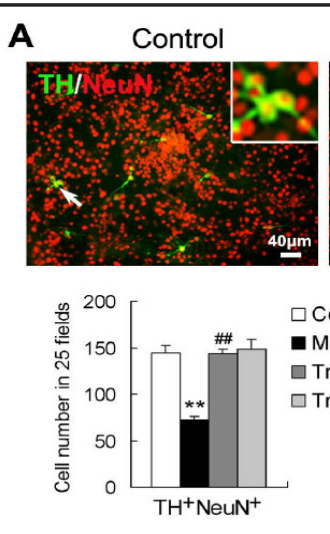

$\square$ Control

- MPP+

$\square$ Treg
$\square$ Treg

$\square$ Treg
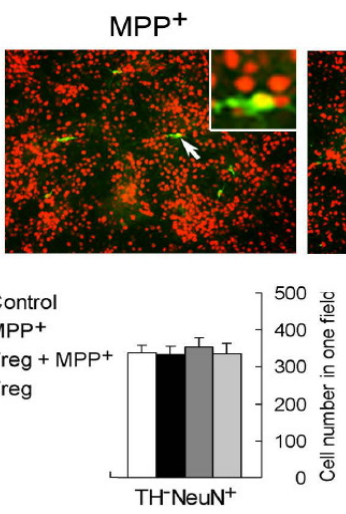

C

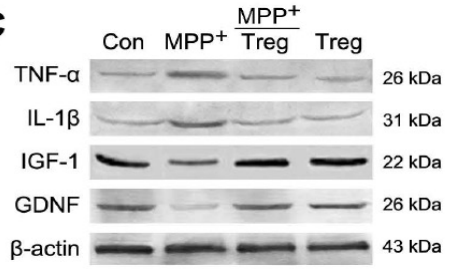

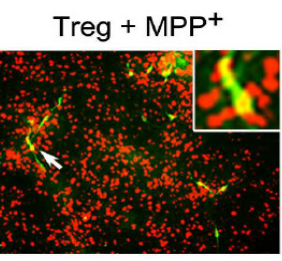

B
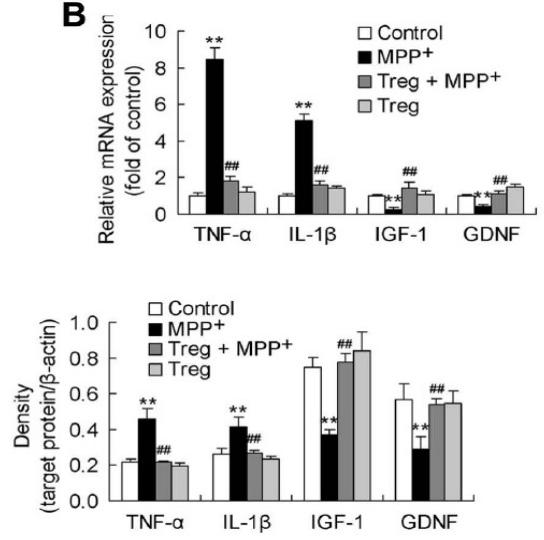

Fig. 1. Treg cells prevent MPP+-induced dopaminergic neuronal loss and glial mediator expression disorders in VM cell cultures. VM cells from E13 \pm 0.5 mice were co-cultured with Treg cells and $1 \mathrm{~h}$ later, MPP ${ }^{+}$ was added to the co-cultures, which were incubated for $24 \mathrm{~h}$ followed by washing to remove the Treg cells. (A) Treg cells prevented MPP-induced $\mathrm{TH}^{+} \mathrm{NeuN}^{+}$cell number decrease but did not affect $\mathrm{TH}^{-} \mathrm{NeuN}^{+}$cell number. In the fluorescence immunostaining images, the $\mathrm{TH}^{+} \mathrm{NeuN}^{+}$neurons indicated by arrows are magnified into the inserted boxes. The statistic histogram below the fluorescence images represents $M \pm S D$ of four independent experiments. For $\mathrm{TH}^{+} \mathrm{NeuN}^{+}$cells, the cell number is the sum in 25 visual fields of a sample, and for $\mathrm{TH}^{-} \mathrm{NeuN}^{+}$cells, the cell number is the average in 5 visual fields of a sample. (B and C) Gene and protein expression of the pro-inflammatory cytokines TNF- $\alpha$ and IL- $1 \beta$ as well as the neurotrophic factors IGF- 1 and GDNF in VM cells. The data were obtained from five or six separate experiments. ${ }^{* *} p<0.01$, versus control; $\# \# p<0.01$, versus $\mathrm{MPP}^{+}$treatment. 


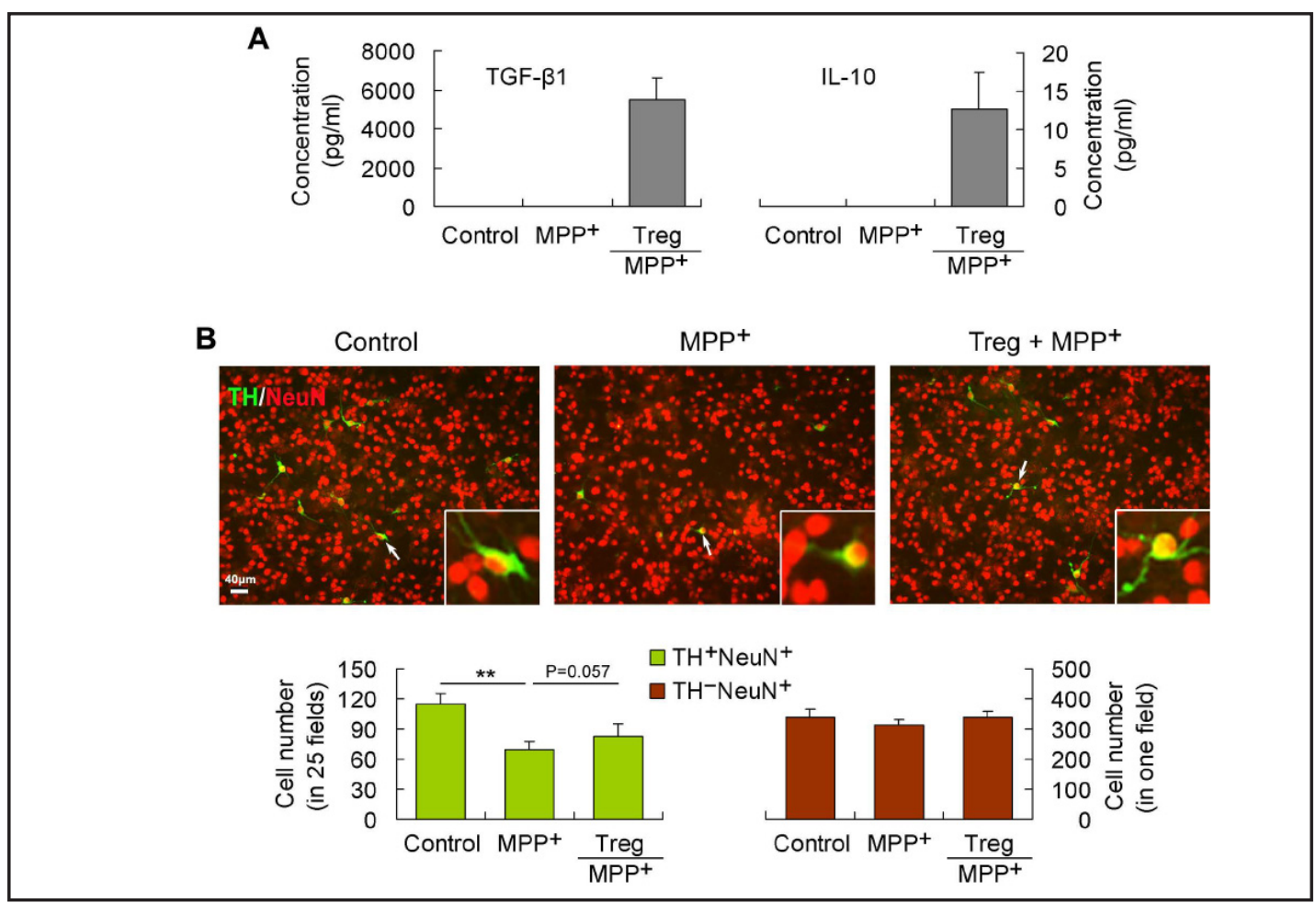

Fig. 2. Treg cells do not significantly prevent $\mathrm{MPP}^{+}$-induced dopaminergic neuronal loss in transwell co-culture. The transwell culture chamber containing Treg cells was placed into the 24-well culture plate containing VM neurons. They were co-cultured for $1 \mathrm{~h}$ and then $\mathrm{MPP}^{+}$was applied to the lower VM neuron cultures. After $24 \mathrm{~h}$ of incubation, the transwell chamber was removed, and the lower neuron cultures were collected and detected. (A) Concentrations of TGF- $\beta 1$ and IL-10 in the supernatants of the lower neuron cultures. These data are from five independent experiments. (B) $\mathrm{TH}^{+} \mathrm{NeuN}^{+}$and $\mathrm{TH}^{-} \mathrm{NeuN}^{+}$cell numbers in the lower neuron cultures. In the fluorescence immunostaining images, the $\mathrm{TH}^{+} \mathrm{NeuN}^{+}$neurons indicated by arrows are magnified into the inserted boxes. The statistic histogram below the fluorescence images represents $\mathrm{M} \pm \mathrm{SD}$ of five independent experiments. For $\mathrm{TH}^{+} \mathrm{NeuN}^{+}$cells, the cell number is the sum in 25 visual fields of a sample, and for $\mathrm{TH}^{-} \mathrm{NeuN}^{+}$cells, the cell number is the average in 5 visual fields of a sample. $* * p<0.01$.

compared with untreated control (Fig. 1A). In contrast, the treatments with $\mathrm{MPP}^{+}$, Treg cells combined with $\mathrm{MPP}^{+}$, or Treg cells alone did not significantly affect $\mathrm{TH}^{-} \mathrm{NeuN}^{+}$cell number (Fig. 1A).

To show glial mediator changes accompanied by the dopaminergic neuronal number alterations, we examined the expression of the pro-inflammatory cytokines TNF- $\alpha$ and IL-1 $\beta$ and the neurotrophic factors IGF-1 and GDNF in VM cell cultures. MPP ${ }^{+}$upregulated TNF- $\alpha$ and IL-1 $\beta$ expression at mRNA and protein levels, but downregulated IGF-1 and GDNF expression (Fig. 1B and C). Treg cells prevented the $\mathrm{MPP}^{+}$-induced disorders in expression of the pro-inflammatory cytokines and the neurotrophic factors (Fig. 1B and C). Treg cell treatment alone did not significantly alter TNF- $\alpha$, IL-1 $\beta$, IGF-1 or GDNF expression compared with untreated control (Fig. 1B and C).

Treg cells do not significantly prevent MPP+-induced dopaminergic neuronal loss in transwell co-culture

The transwell cell culture chamber containing Treg cells was placed into the VM neuron culture plate. The co-culture blocked Treg cells to directly act on the neurons, but cytokines secreted from Treg cells were able to infiltrate into the lower neuron cultures to affect the neurons. As expected, in the lack of Treg cell treatment, the cytokines TGF- $\beta 1$ and IL-10 were not able to be detected in the supernatants of lower VM neuron cultures regardless of control 


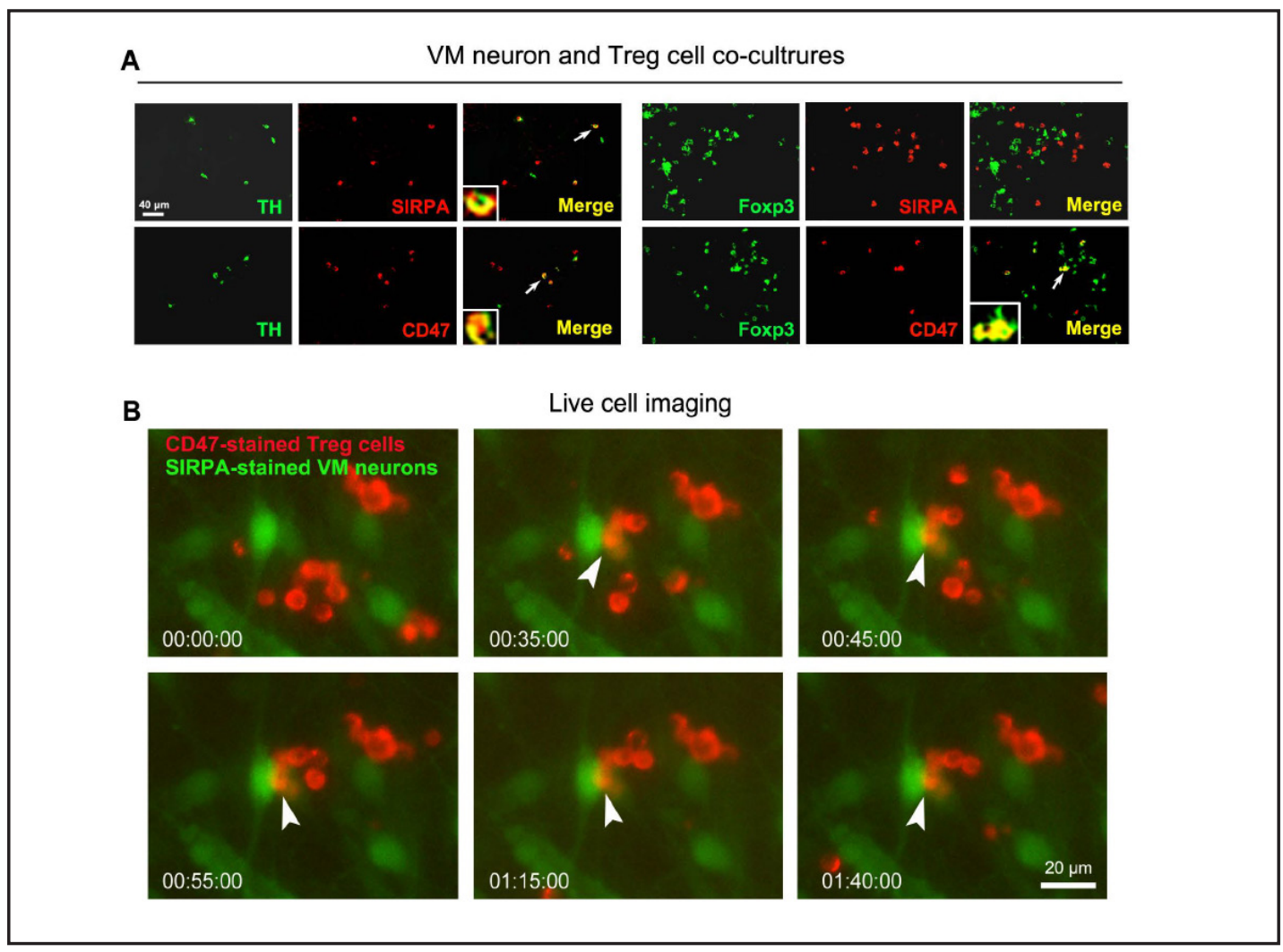

Fig. 3. CD47 and SIRPA are expressed by Treg cells and/or dopaminergic neurons and they mediate a direct contact of Treg cells with the neurons. (A) Co-expression of TH (dopaminergic neuron marker) with CD47 or SIRPA as well as co-expression of Foxp3 (Treg cell marker) with CD47 or SIRPA were examined in VM neuron and Treg cell co-cultures. The typical overlapped cells are pointed at by arrows and magnified in the insets. (B) A dynamic contact of CD47 ${ }^{+}$Treg cells with SIRPA+ VM neurons was captured by the live cell imaging system. Treg cells and VM neurons were stained with CD47 and SIRPA, respectively. After staining, Treg cells were co-cultured with VM neurons in a chamber, which was placed in a live cell imaging system. The images were taken every $20 \mathrm{~s}$ for up to $6 \mathrm{~h}$. The arrowheads indicate a dynamic contact of CD47-labeled Treg cells (red) with SIRPA-labeled VM neurons (green).

or $\mathrm{MPP}^{+}$treatment (Fig. 2A). In contrast, in Treg cell co-culture with VM neurons via the transwell system, both TGF- $\beta 1$ and IL-10 levels significantly increased in the supernatants of lower VM neuron cultures treated by $\mathrm{MPP}^{+}$(Fig. 2A). Importantly, $\mathrm{MPP}^{+}$-induced $\mathrm{TH}^{+} \mathrm{NeuN}^{+}$ cell loss in the lower VM neuron cultures was not significantly ameliorated by the Treg cell transwell treatment compared with that lacking Treg cell transwell treatment $(\mathrm{P}=0.057$, Fig. 2B). For $\mathrm{TH}^{-} \mathrm{NeuN} \mathrm{N}^{+}$cells in the lower VM neuron cultures, the treatments with $\mathrm{MPP}^{+}$or Treg cell transwell co-culture did not significantly alter the cell number compared with untreated control (Fig. 2B).

CD47 and SIRPA are expressed by Treg cells and/or dopaminergic neurons and mediate a direct contact of Treg cells with the neurons

Since Treg cell cytokines did not prevent $\mathrm{MPP}^{+}$-induced dopaminergic neuronal loss, a Treg-to-neuron cell contact protection via an interaction between the two transmembrane proteins CD47 and SIRPA was examined. CD47 was expressed by both $\mathrm{TH}^{+}$cells and Foxp3 ${ }^{+}$ cells in VM neuron and Treg cell co-cultures, while SIRPA was expressed only by $\mathrm{TH}^{+}$cells (Fig. 3A). Notably, a dynamic contact of CD47-stained Treg cells with SIRPA-stained VM neurons was captured by live cell imaging system (Fig. 3B and for online suppl. material, see www.karger.com/doi/10.1159/000464388).

\section{KARGER}




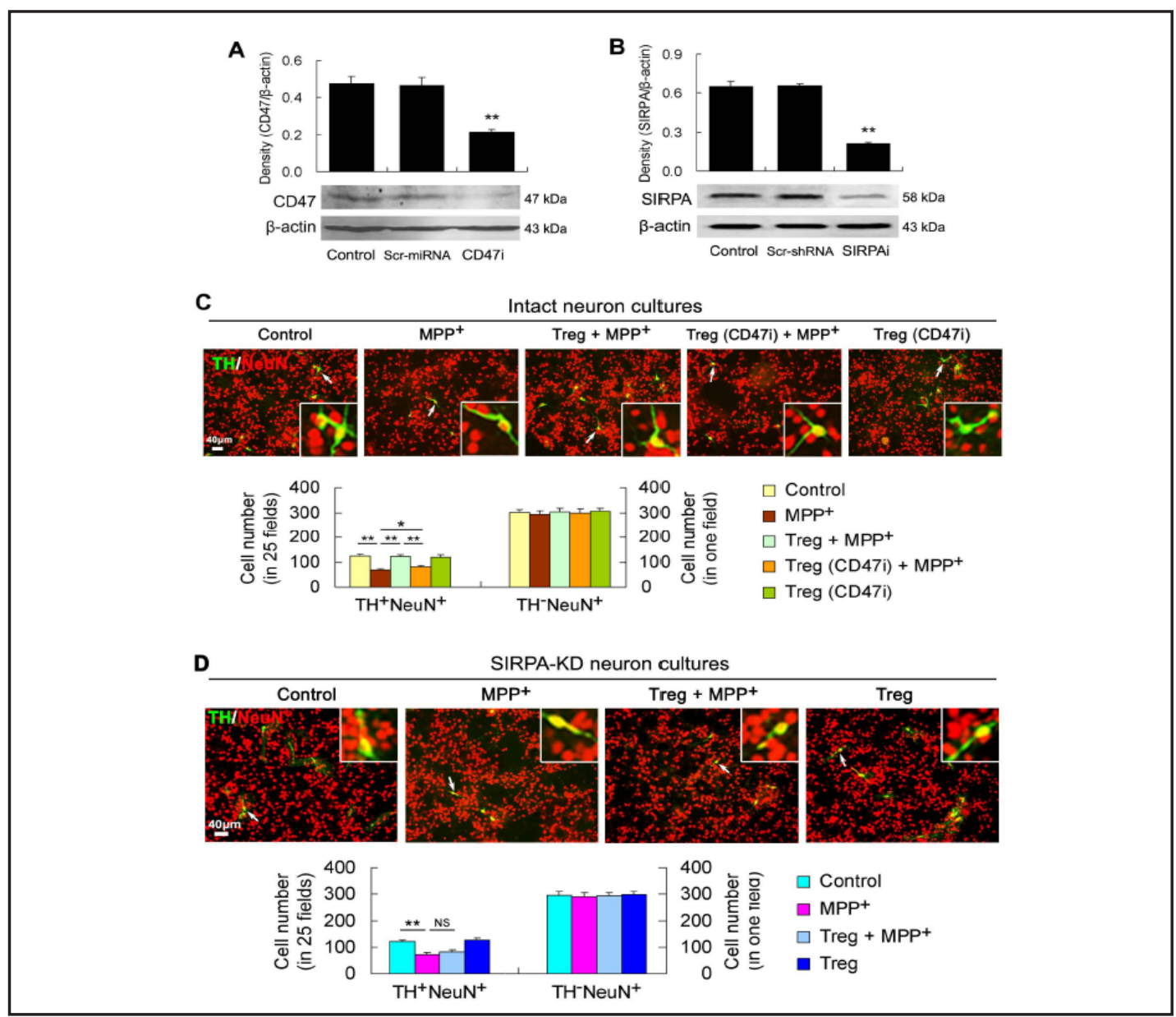

Fig. 4. CD47-SIRPA interaction mediates Treg cell protection against MPP+-induced dopaminergic neuronal loss. (A) Treg cells transfected with CD47-miRNA were incubated for $48 \mathrm{~h}$, and the silencing efficiency was assessed by Western blotting analysis. (B) VM neurons transfected with SIRPA-shRNA were cultured for 72 $\mathrm{h}$, and the silencing efficiency was assessed by Western blotting analysis. In (A) and (B), the statistic data are from three repetitions, and ${ }^{* *} p<0.01$, versus control or scrambled sequences. (C) Treg cells transfected with CD47-miRNA (CD47i) were co-incubated with VM neurons for $1 \mathrm{~h}$, and $\mathrm{MPP}^{+}$was added to the co-cultures, which were incubated for $24 \mathrm{~h}$ followed by washing to remove Treg cells. $\mathrm{TH}^{+} \mathrm{NeuN}^{+}$and $\mathrm{TH}^{-} \mathrm{NeuN}^{+}$cell numbers in the VM neurons were counted as described in Fig. 1. In the fluorescence immunostaining images, the $\mathrm{TH}^{+} \mathrm{NeuN}{ }^{+}$neurons indicated by arrows are magnified in the insets. The statistic histogram below the fluorescence images is $\mathrm{M} \pm \mathrm{SD}$ of four independent experiments. (D) VM neurons transfected with SIRPA-shRNA (SIRPA-KD) were co-cultured with Treg cells for $1 \mathrm{~h}$, and $\mathrm{MPP}^{+}$was added to the co-cultures, which were incubated for $24 \mathrm{~h}$ followed by washing to remove Treg cells. $\mathrm{TH}^{+} \mathrm{NeuN}^{+}$and $\mathrm{TH}^{-} \mathrm{NeuN}^{+}$cell numbers in the SIRPA-KD neurons were counted as described in Fig. 1. In the fluorescence immunostaining images, the $\mathrm{TH}^{+} \mathrm{NeuN}{ }^{+}$neurons indicated by arrows are magnified in the insets. The statistic histogram below the fluorescence images is $\mathrm{M} \pm \mathrm{SD}$ of four independent experiments. ${ }^{*} p<0.05$; ${ }^{*} p<0.01$; NS: no significance.

\section{CD47-SIRPA interaction mediates Treg cell protection against MPP+-induced dopaminergic neuronal loss and neuronal apoptosis}

Treg-to-neuron cell contact protection depending on CD47-SIRPA interaction was assessed by silencing CD47 gene in Treg cells and silencing SIRPA gene in VM neurons, respectively. Both CD47 expression in Treg cells transfected with CD47-miRNA and SIRPA expression in VM neurons transfected with SIRPA-shRNA were downregulated, with respect to scrambled miRNA and shRNA sequences, respectively (Fig. 4A and B). $\mathrm{MPP}^{+}$decreased $\mathrm{TH}^{+} \mathrm{NeuN}{ }^{+}$cell number in VM neuron cultures, and Treg cells prevented the MPP+-induced 


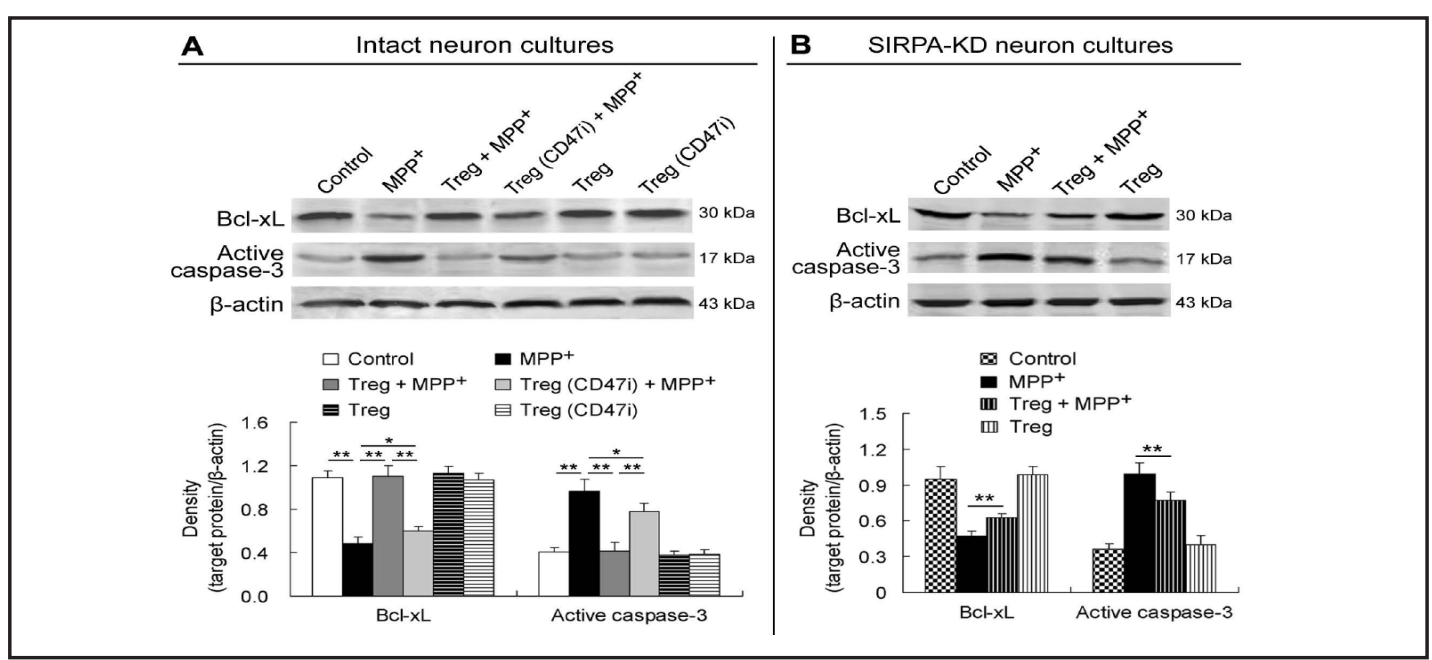

Fig. 5. CD47-SIRPA interaction mediates Treg cell protection against $\mathrm{MPP}^{+}$-induced VM neuronal apoptosis. The design of the experiments was similar to that of Fig. 4. (A) Silencing CD47 (CD47i) in Treg cells reduced the effects of Treg cells preventing $\mathrm{MPP}^{+}$-induced expression downregulation of the anti-apoptotic protein Bcl-xL and expression upregulation of the pro-apoptotic enzyme active caspase-3 in VM neurons. (B) Silencing SIRPA (SIRPA-KD) in VM neurons reduced the effects of Treg cells preventing MPP+-induced Bcl-xL expression downregulation and active caspase- 3 expression upregulation in the neurons. These experiments were repeated four times. ${ }^{*} p<0.05 ;{ }^{* *} p<0.01$.

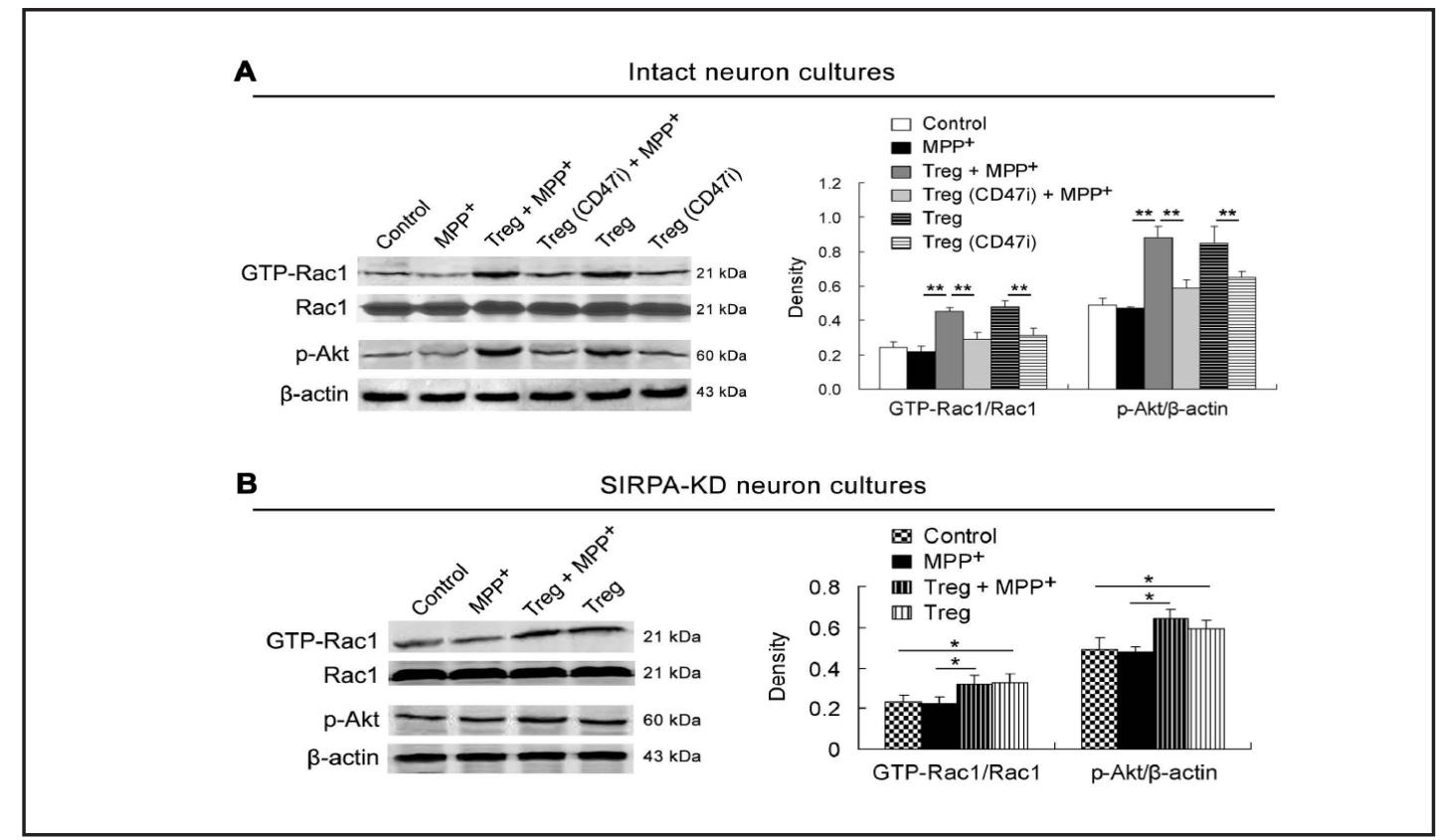

Fig. 6. Treg cells activate neuronal Rac1/Akt signaling via CD47-SIRPA interaction. Treg cells transfected with CD47-miRNA (CD47i) were co-incubated with VM neurons for $1 \mathrm{~h}$, and $\mathrm{MPP}^{+}$was added to the co-cultures, which were incubated for $24 \mathrm{~h}$ followed by washing to remove Treg cells. (A) Silencing CD47 (CD47i) in Treg cells reduced the Treg cells-induced Rac1 and Akt activation in VM neurons regardless of the presence or the absence of MPP+. (B) Silencing SIRPA (SIRPA-KD) in VM neurons reduced Treg-induced Rac1 and Akt activation in the neurons. The ratios of GTP-Rac1/Rac1 and p-Akt/ $\beta$-actin were considered as activation levels of Rac1 and Akt, respectively. These statistic data are from five separate experiments. ${ }^{*} p<0.05$; ${ }^{* *} p<0.01$.

$\mathrm{TH}^{+} \mathrm{NeuN}{ }^{+}$cell loss (Fig. 4C). Silencing CD47 gene in Treg cells reduced the protection of Treg cells against $\mathrm{MPP}^{+}$neurotoxicity (Fig. 4C). Moreover, in SIRPA-knockdown VM neurons, Treg 


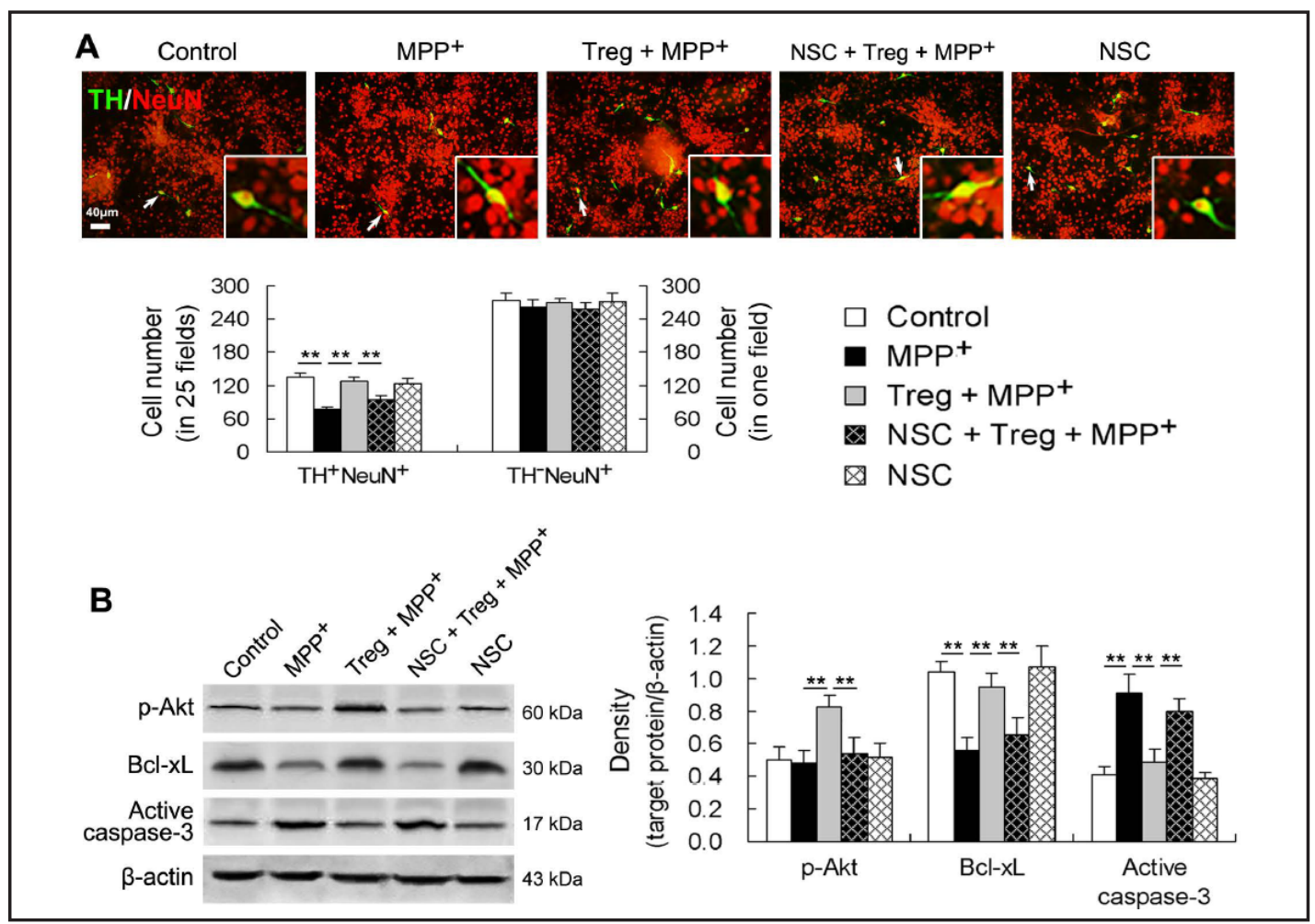

Fig. 7. Inhibiting neuronal Rac1/Akt signaling with NSC23766 (NSC) reduces Treg cell neuroprotection against $\mathrm{MPP}^{+}$toxicity. VM neurons were treated with the Rac1 activation inhibitor NSC for 30 min and then the neurons were co-cultured with Treg cells in the presence of $\mathrm{MPP}^{+}$for $24 \mathrm{~h}$, followed by washing to remove Treg cells. The remaining VM neurons were collected and estimated for $\mathrm{TH}^{+} \mathrm{NeuN}^{+}$and $\mathrm{TH}^{-} \mathrm{NeuN}^{+}$cell numbers (A) as well as for expression levels of the apoptosis-related markers and activation level of the Rac1 downstream signaling Akt (B). The statistic graphs represent five independent experiments. ${ }^{* *} p<0.01$.

cells did not prevent $\mathrm{MPP}^{+}$-induced $\mathrm{TH}^{+} \mathrm{NeuN}^{+}$cell loss (Fig. 4D). In contrast, $\mathrm{TH}^{-} \mathrm{NeuN}^{+}$cell number in VM neuron cultures was not significantly altered by the treatments with MPP', Treg cells, or gene interference (Fig. 4C and D).

In addition to assessing dopaminergic neuronal number, the anti-apoptotic molecule Bcl-xL and the pro-apoptotic enzyme active caspase- 3 were tested for confirming the Treg cell contact protection. As expected, $\mathrm{MPP}^{+}$downregulated $\mathrm{Bcl}-\mathrm{xL}$ expression but upregulated active caspase-3 expression in VM neurons (Fig. 5A). Treg cells prevented the MPP+-induced changes in expression of the apoptosis-related markers (Fig. 5A). Significantly, silencing CD47 gene in Treg cells reduced the protection of Treg cells against MPP'-induced neuronal apoptosis (Fig. 5A). Similarly, $\mathrm{MPP}^{+}$downregulated Bcl-xL expression and upregulated active caspase-3 expression in SIRPA-knockdown VM neurons (Fig. 5B). Although the combined treatment with Treg cells and $\mathrm{MPP}^{+}$increased Bcl-xL expression and decreased active caspase- 3 expression compared with $\mathrm{MPP}^{+}$treatment alone in SIRPA-knockdown VM neurons, it did not recover both the protein expression to a control level (Fig. 5B). This result showed that silencing SIRPA gene in VM neurons reduced Treg cell protection against MPP+induced neuronal apoptosis.

Treg cells activate neuronal Rac1/Akt signaling via CD47-SIRPA interaction

A CD47-SIRPA downstream signaling pathway Rac1/Akt in VM neurons was examined to determine whether this pathway is involved in Treg cell neuroprotection. Activation level of Rac1 was assessed by a ratio between densitometric values of GTP-bound and total Rac1; and activation level of Akt was assessed by Akt phosphorylation level normalized to $\beta$-actin. Treg cells enhanced both Rac1 and Akt activation in VM neurons in either the presence or the KARGER 


\section{Cellular Physiology Cell Physiol Biochem 2017;41:1240-1254 \\ \begin{tabular}{l|l} 
and Biochemistry Published onIIne: March 07, 2017 & $\begin{array}{l}\text { C } 2017 \text { The Author(s). Published by S. Karger AG, Basel } \\
\text { www.karger.com/cpb }\end{array}$
\end{tabular} \\ Huang et al.: Treg Cells Protect Neurons against MPP+ Toxicity}

absence of $\mathrm{MPP}^{+}$(Fig. 6A). Silencing CD47 gene in Treg cells reduced the effects of Treg cells activating neuronal Rac1/Akt signaling pathway regardless of the presence or the absence of $\mathrm{MPP}^{+}$(Fig. 6A). In addition, although Treg cells still activated Rac1/Akt signaling pathway in SIRPA-knockdown neurons in the presence or the absence of $\mathrm{MPP}^{+}$, the ability of Treg cells to activate Rac1/Akt signaling in SIRPA-knockdown neurons was 2.5 -fold lower than in intact neurons (Fig. 6B).

Inhibiting neuronal Rac1/Akt signaling pathway reduces Treg cell neuroprotection against $M P P^{+}$toxicity

To demonstrate that neuronal Rac1/Akt signaling pathway mediates the contact neuroprotection of Treg cells, we applied NSC23766, an inhibitor of Rac1 activation, to VM neuron cultures before Treg cell treatment. The effect of Treg cells preventing $\mathrm{MPP}^{+}$-induced $\mathrm{TH}^{+} \mathrm{NeuN}^{+}$cell loss was reduced by NSC23766 (Fig. 7A). NSC23766 treatment alone did not significantly alter $\mathrm{TH}^{+} \mathrm{NeuN}^{+}$cell number compared with untreated control (Fig. 7A). In contrast, these same treatments did not affect $\mathrm{TH}^{-} \mathrm{NeuN}^{+}$cell number (Fig. 7A). Moreover, as shown above, both the downregulated Bcl-xL expression and the upregulated active caspase-3 expression in VM neurons caused by $\mathrm{MPP}^{+}$were prevented by Treg cells (Fig. 7B). Importantly, NSC23766 impaired the Treg cell protection against MPP+-induced neuronal apoptosis (Fig. 7B). Simultaneously, neuronal Akt activation by Treg cells was inhibited by NSC23766 (Fig. 7B). NSC23766 exposure alone did not significantly alter neuronal apoptosis and Akt activation compared with untreated control (Fig. 7B).

\section{Discussion}

In the present study, Treg cells prevented $\mathrm{MPP}^{+}$-induced dopaminergic neuronal loss, pro-inflammatory cytokine upregulation, and neurotrophic factor downregulation in VM cell cultures that included neurons and glia, demonstrating that Treg cells exert neuroprotective effect. The pro-inflammatory cytokines TNF- $\alpha$ and IL- $1 \beta$ as well as the neurotrophic factors IGF-1 and GDNF are predominantly expressed by glia [35, 36]. Therefore, the prevention of the glial mediator disorders by Treg cells suggests that Treg cells inhibit glial activation and inflammatory response. As a support, Reynolds et al. [6] have shown that Treg cells mediate neuroprotection through modulation of microglial oxidative stress and inflammation. Indeed, Treg cells, as important immunosuppressive cells, are better understood to inhibit glial activation and inflammatory response to exert neuroprotective property. As a comparison, our recent work demonstrated that $\mathrm{CD}^{+} \mathrm{CD}^{2} 5^{-}$Th17 cells exacerbated $\mathrm{MPP}^{+}$-induced dopaminergic neuronal loss and pro-inflammatory/neurotrophic factor disorders in VM cell cultures [7]. These results show that the two T cell subsets $\mathrm{CD} 4^{+} \mathrm{CD} 25^{-} \mathrm{Th} 17$ and $\mathrm{CD} 4^{+} \mathrm{CD} 25^{+}$ Treg have opposite effects on dopaminergic neuronal survival by a pro-inflammatory and anti-inflammatory property, respectively.

In addition to the indirect action of Treg cells on neurons via the glial mediation, we hypothesized that Treg cells directly act on dopaminergic neurons to perform neuroprotection. The cytokines TGF- $\beta 1$ and IL-10 secreted from Treg cells are important in transmitting Treg cell immunosuppressive effects [10, 37]. However, in transwell coculture of Treg cells and VM neurons, TGF- $\beta 1$ and IL-10 released from Treg cells did not significantly protect dopaminergic neurons against $\mathrm{MPP}^{+}$toxicity in the current study. The findings suggest that Treg cells do not depend on their cytokines to exert the direct neuroprotective effect. In fact, we have recently demonstrated that microglia are a required target for TGF- $\beta 1$ neuroprotection against $\mathrm{MPP}^{+}$toxicity [19]. Thus, a cell-to-cell (Treg-toneuron) communication with the aid of cell surface molecules becomes a key mechanism underlying Treg cell neuroprotection.

CD47 was expressed on both Treg cells and dopaminergic neurons, and SIRPA was expressed only on dopaminergic neurons in this study. These data are consistent with other reports that CD47 is expressed on virtually all cells, whereas SIRPA is predominantly 


\section{Cellular Physiology Cell Physiol Biochem 2017;41:1240-1254

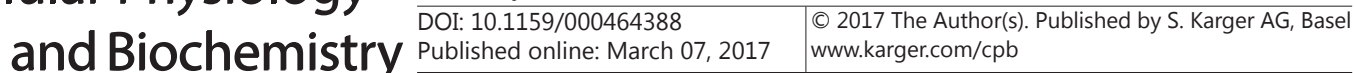 \\ Huang et al.: Treg Cells Protect Neurons against MPP+ Toxicity}

expressed on phagocytic and neuronal cells, being barely detectable in $\mathrm{T}$ or $\mathrm{B}$ cells $[21,38$ 40]. Importantly, live cell imaging system captured a dynamic contact of CD47-stained Treg cells with SIRPA-stained VM neurons in the present study. The findings provide substantial evidence for Treg-to-neuron communication. More importantly, either silencing CD47 gene in Treg cells or silencing SIRPA gene in VM neurons reduced the protection of Treg cells against $\mathrm{MPP}^{+}$-induced dopaminergic neuronal loss and neuronal cell apoptosis. These results demonstrate that CD47-SIRPA interaction is crucial in mediating Treg cell protection to dopaminergic neurons. CD47-SIRPA interaction is clearly important to homeostatic regulation of myeloid cell function, particularly these cells' phagocytic activity [41]. However, information on functions of CD47-SIRPA signaling pathway in the brain remains limited, although putative roles of CD47 and SIRPA have been addressed individually [16]. These various observations indicate that CD47-SIRPA signaling pathway might participate in regulation of hippocampus-dependent memory formation, of central responses to stress, and of the autonomic nervous system [16]. Here, we provide new evidence for CD47-SIRPA interaction between immune cells and neurons, establishing that the interaction of CD47 on Treg cells with SIRPA on dopaminergic neurons mediates Treg cell neuroprotection.

CD47/SIRPA downstream signaling involves Rac1/Akt pathway [16, 42]. This pathway plays an important role in regulating neuronal survival and inhibiting neuronal apoptosis $[43,44]$. Rac1 has been shown to promote cell survival via Akt [45]. In the present study, Treg cells activated neuronal Rac1/Akt signaling pathway, suggesting that Rac1/Akt pathway is involved in Treg cell action on neurons. Further investigation revealed that either silencing CD47 in Treg cells or silencing SIRPA in neurons reduced the Treg-induced neuronal Rac1/ Akt activation. These findings indicate that neuronal Rac1/Akt activation at least in part depends on CD47-SIRPA interaction between Treg cells and neurons. The inhibition of Treg-induced neuronal Rac1/Akt activation with NSC23766 reduced the neuroprotection of Treg cells against $\mathrm{MPP}^{+}$toxicity. These results suggest that neuronal Rac1/Akt activation depending on the interaction of CD47 and SIRPA is an intracellular signaling mechanism for Treg cell neuroprotection.

In summary, Treg cells protect dopaminergic neurons against $\mathrm{MPP}^{+}$toxicity by inhibiting glial pro-inflammatory response. In addition to the indirect action of Treg cells on neurons via the glial mediation, Treg cells can directly protect dopaminergic neurons against $\mathrm{MPP}^{+}-$ induced neuronal loss and apoptosis. This direct neuroprotection by Treg cells does not depend on the cytokines TGF- $\beta 1$ and IL-10 secreted from Treg cells, but depends on a cellto-cell (Treg-to-neuron) contact mechanism. Interaction of CD47 on Treg cells with SIRPA on dopaminergic neurons contributes to the contact protection of Treg cells to the neurons. Simultaneously, the CD47-SIRPA interaction between Treg cells and neurons activates neuronal Rac1/Akt signaling pathway and this pathway mediates Treg cell neuroprotection. These findings provide a new insight into promotion of Treg-to-neuron intercellular communication as a therapeutic strategy for PD.

\section{Acknowledgments}

This work was supported by grants 81271323 and 31371182 from the National Natural Science Foundation of China, MS12015104 and MS12015096 from the Nantong Applied Research Program of China, and a project funded by the Priority Academic Program Development (PAPD) of Jiangsu Higher Education Institutions.

\section{Disclosure Statement}

The authors declare no conflict of interest. 


\section{Cellular Physiology Cell Physiol Biochem 2017;41:1240-1254 \begin{tabular}{l|l|l} 
and Biochemistry Published onlıne: March 07, 2017 & $\begin{array}{l}\text { (c) } 2017 \text { The Author(s). Published by S. Karger AG, Basel } \\
\text { www.karger.com/cpb }\end{array}$
\end{tabular}}

\section{References}

1 Olson KE, Kosloski-Bilek LM, Anderson KM, Diggs BJ, Clark BE, Gledhill JM Jr, Shandler SJ, Mosley RL, Gendelman HE: Selective VIP Receptor Agonists Facilitate Immune Transformation for Dopaminergic Neuroprotection in MPTP-Intoxicated Mice. J Neurosci 2015;35:16463-16478.

-2 Kosloski LM, Kosmacek EA, Olson KE, Mosley RL, Gendelman HE: GM-CSF induces neuroprotective and anti-inflammatory responses in 1-methyl-4-phenyl-1,2,3,6-tetrahydropyridine intoxicated mice. J Neuroimmunol 2013;265:1-10.

3 Dansokho C, Ait Ahmed D, Aid S, Toly-Ndour C, Chaigneau T, Calle V, Cagnard N, Holzenberger M, Piaggio E, Aucouturier P, Dorothée G: Regulatory T cells delay disease progression in Alzheimer-like pathology. Brain 2016;139:1237-1251.

4 Chung ES, Lee G, Lee C, Ye M, Chung HS, Kim H, Bae SJ, Hwang DS, Bae H: Bee Venom Phospholipase A2, a Novel Foxp3+ Regulatory T Cell Inducer, Protects Dopaminergic Neurons by Modulating Neuroinflammatory Responses in a Mouse Model of Parkinson's Disease. J Immunol 2015;195:4853-4860.

5 González H, Contreras F, Pacheco R: Regulation of the Neurodegenerative Process Associated to Parkinson's Disease by CD4+ T-cells. J Neuroimmune Pharmacol 2015;10:561-575.

-6 Reynolds AD, Stone DK, Hutter JA, Benner EJ, Mosley RL, Gendelman HE: Regulatory T cells attenuate Th17 cell-mediated nigrostriatal dopaminergic neurodegeneration in a model of Parkinson's disease. J Immunol 2010;184:2261-2271.

7 Liu Z, Huang Y, Cao BB, Qiu YH, Peng YP: Th17 cells induce dopaminergic neuronal death via LFA-1/ICAM-1 interaction in a mouse model of Parkinson's disease. Mol Neurobiol DOI:10.1007/s12035-016-0249-9.

-8 Sakaguchi S: Naturally arising CD4+ regulatory t cells for immunologic self-tolerance and negative control of immune responses. Annu Rev Immunol 2004;22:531-562.

-9 Sakaguchi S, Yamaguchi T, Nomura T, Ono M: Regulatory T cells and immune tolerance. Cell 2008;133:775787.

10 Noack M, Miossec P: Th17 and regulatory T cell balance in autoimmune and inflammatory diseases. Autoimmun Rev 2014;13:668-677.

11 Shen Y, Wei Y, Wang Z, Jing Y, He H, Yuan J, Li R, Zhao Q Wei L, Yang T, Lu J: TGF- $\beta$ regulates hepatocellular carcinoma progression by inducing Treg cell polarization. Cell Physiol Biochem 2015;35:1623-1632.

12 Wang Y, Liu T, Tang W, Deng B, Chen Y, Zhu J, Shen X: Hepatocellular Carcinoma Cells Induce Regulatory T Cells and Lead to Poor Prognosis via Production of Transforming Growth Factor- $\beta 1$. Cell Physiol Biochem 2016;38:306-318.

13 He F, Balling R: The role of regulatory T cells in neurodegenerative disease. Wiley Interdiscip Rev Syst Biol Med 2013;5:153-180.

-14 Saunders JA, Estes KA, Kosloski LM, Allen HE, Dempsey KM, Torres-Russotto DR, Meza JL, Santamaria PM, Bertoni JM, Murman DL, Ali HH, Standaert DG, Mosley RL, Gendelman HE: CD4+ T cell subsets profile motor dysfunction in Parkinson's disease. J Neuroimmune Pharmacol 2012;7:927-938.

15 Reynolds AD, Banerjee R, Liu J, Gendelman HE, Mosley RL: Neuroprotective activities of CD4+CD25+ regulatory T cells in an animal model of Parkinson's disease. J Leukoc Biol 2007;82:1083-1094.

16 Matozaki T, Murata Y, Okazawa H, Ohnishi H: Functions and molecular mechanisms of the CD47-SIRPA signalling pathway. Trends Cell Biol 2009;19:72-80.

17 Mills KH: Regulatory T cells: friend or foe in immunity to infection? Nat Rev Immunol 2004;4:841-855.

18 Wan YY, Flavell RA: TGF-beta and regulatory T cell in immunity and autoimmunity. J Clin Immunol 2008;28:647-659.

19 Liu Z, Chen HQ Huang Y, Qiu YH, Peng YP: Transforming growth factor- $\beta 1$ acts via T $\beta$ R-I on microglia to protect against MPP(+)-induced dopaminergic neuronal loss. Brain Behav Immun 2016;51:131-143.

-20 Mayo L, Cunha AP, Madi A, Beynon V, Yang Z, Alvarez JI, Prat A, Sobel RA, Kobzik L, Lassmann H, Quintana FJ, Weiner HL: IL-10-dependent Tr1 cells attenuate astrocyte activation and ameliorate chronic central nervous system inflammation. Brain 2016;139:1939-1957.

-21 Brown EJ, Frazier WA: Integrin-associated protein (CD47) and its ligands. Trends Cell Biol 2001;11:130135.

-22 Jiang P, Lagenaur CF, Narayanan V: Integrin-associated protein is a ligand for the P84 neural adhesion molecule. J Biol Chen 1999;274:559-562.

-23 Adams S, van der Laan LJ, Vernon-Wilson E, Renardel de Lavalette C, Döpp EA, Dijkstra CD, Simmons DL, van den Berg TK: Signal-regulatory protein is selectively expressed by myeloid and neuronal cells. J Immunol 1998;161:1853-1859. 


\section{Cellular Physiology Cell Physiol Biochem 2017;41:1240-1254 \begin{tabular}{ll|l} 
and Biochemistry Published onlıne: March 07, 2017 & $\begin{array}{l}\text { (c) } 2017 \text { The Author(s). Published by S. Karger AG, Basel } \\
\text { www.karger.com/cpb }\end{array}$
\end{tabular}}

Huang et al.: Treg Cells Protect Neurons against MPP+ Toxicity

24 Seiffert M, Brossart P, Cant C, Cella M, Colonna M, Brugger W, Kanz L, Ullrich A, Bühring HJ: Signalregulatory protein $\alpha(\operatorname{SIRP} \alpha)$ but not SIRP $\beta$ is involved in T-cell activation, binds to CD47 with high affinity, and is expressed on immature CD34+CD38- hematopoietic cells. Blood 2001;97:2741-2749.

25 Johansen ML, Brown EJ: Dual regulation of SIRP $\alpha$ phosphorylation by integrins and CD47. J Biol Chem 2007;282:24219-24230.

-26 Murata Y, Kotani T, Ohnishi H, Matozaki T: The CD47-SIRP $\alpha$ signalling system: its physiological roles and therapeutic application. J Biochem 2014;155:335-344.

-27 Oldenborg PA, Zheleznyak A, Fang YF, Lagenaur CF, Gresham HD, Lindberg FP: Role of CD47 as a marker of self on red blood cells. Science 2000;288:2051-2054.

28 Okazawa H, Motegi S, Ohyama N, Ohnishi H, Tomizawa T, Kaneko Y, Oldenborg PA, Ishikawa O, Matozaki T: Negative regulation of phagocytosis in macrophages by the CD47-SHPS-1 system. J Immunol 2005; 174:2004-2011.

29 Barclay AN: Signal regulatory protein alpha (SIRPA)/CD47 interaction and function. Curr Opin Immunol 2009;21: 47-52.

-30 Chen BC, Kang JC, Lu YT, Hsu MJ, Liao CC, Chiu WT, Yeh FL, Lin CH: Rac1 regulates peptidoglycan-induced nuclear factor-kappaB activation and cyclooxygenase-2 expression in RAW 264.7 macrophages by activating the phosphatidylinositol 3-kinase/Akt pathway. Mol Immunol 2009;46:1179-1188.

-31 Cicenas J: The potential role of Akt phosphorylation in human cancers. Int J Biol Markers 2008;23:1-9.

-32 Qian L, Wei SJ, Zhang D, Hu X, Xu Z, Wilson B, El-Benna J, Hong JS, Flood PM: Potent anti-inflammatory and neuroprotective effects of TGF-beta1 are mediated through the inhibition of ERK and p47phox-Ser345 phosphorylation and translocation in Microglia. J Immunol 2008;181:660-668.

-33 Qian L, Block ML, Wei SJ, Lin CF, Reece J, Pang H, Wilson B, Hong JS, Flood PM: Interleukin-10 protects lipopolysaccharide induced neurotoxicity in primary midbrain cultures by inhibiting the function of NADPH oxidase. J Pharmacol Exp Ther 2006;319:44-52.

-34 Liu J, Gong N, Huang X, Reynolds AD, Mosley RL, Gendelman HE: Neuromodulatory activities of CD4+CD25+ regulatory T cells in a murine model of HIV-1-associated neurodegeneration. J Immunol 2009;182:38553865 .

-35 Spitzbarth I, Baumgärtner W, Beineke A: The role of pro- and anti-inflammatory cytokines in the pathogenesis of spontaneous canine CNS disease. Vet Immunol Immunopathol 2012;147:6-24.

-36 Becher B, Spath S, Goverman J: Cytokine networks in neuroinflammation. Nat Rev Immunol 2017;17:49_ 59.

37 Yeh H, Moore DJ, Markmann JF, Kim JI: Mechanisms of regulatory T cell counter-regulation by innate immunity. Transplant Rev (Orlando) 2013;27:61-64.

38 Kharitonenkov A, Chen Z, Sures I, Wang H, Schilling J, Ullrich A: A family of proteins that inhibit signalling through tyrosine kinase receptors. Nature 1997;386:181-186.

-39 Lv Z, Bian Z, Shi L, Niu S, Ha B, Tremblay A, Li L, Zhang X, Paluszynski J, Liu M, Zen K, Liu Y: Loss of cell surface CD47 clustering formation and binding avidity to SIRP $\alpha$ facilitate apoptotic cell clearance by macrophages. J Immunol 2015;195:661-671.

40 Washio K, Kotani T, Saito Y, Respatika D, Murata Y, Kaneko Y, Okazawa H, Ohnishi H, Fukunaga A, Nishigori C, Matozaki T: Dendritic cell SIRP $\alpha$ regulates homeostasis of dendritic cells in lymphoid organs. Genes Cells 2015;20:451-463.

41 Barclay AN, Van den Berg TK: The interaction between signal regulatory protein alpha (SIRP $\alpha$ ) and CD47: structure, function, and therapeutic target. Annu Rev Immunol 2014;32: 25-50.

42 Wang L, Lu Y, Deng S, Zhang Y, Yang L, Guan Y, Matozaki T, Ohnishi H, Jiang H, Li H: SHPS-1 deficiency induces robust neuroprotection against experimental stroke by attenuating oxidative stress. J Neurochem 2012;122:834-843.

43 Le SS, Loucks FA, Udo H, Richardson-Burns S, Phelps RA, Bouchard RJ, Barth H, Aktories K, Tyler KL, Kandel ER, Heidenreich KA, Linseman DA: Inhibition of Rac GTPase triggers a c-Jun- and Bim-dependent mitochondrial apoptotic cascade in cerebellar granule neurons. J Neurochem 2005;94:1025-1039.

-44 Stankiewicz TR, Ramaswami SA, Bouchard RJ, Aktories K, Linseman DA: Neuronal apoptosis induced by selective inhibition of Rac GTPase versus global suppression of Rho family GTPases is mediated by alterations in distinct mitogen-activated protein kinase signaling cascades. J Biol Chem 2015;290:93639376.

45 Burgering BM, Coffer PJ: Protein kinase B (c-Akt) in phosphatidylinositol-3-OH kinase signal transduction. Nature 1995;376:599-602. 